LISANUL ARAB 10 (2)(2021)
(Terakreditasi Sinta 4)
http://journal.unnes.ac.id/sju/index.php/laa

\title{
PENGEMBANGAN POCKETBOOK PEMBELAJARAN MUFRADÂT BERBASIS ANTI RADIKALISME BAGI MAHASISWA JURUSAN PENDIDIKAN BAHASA ARAB
}

\author{
Jauhar Ali凶 \\ IAIN Pekalongan, Indonesia
}

\begin{tabular}{l}
\hline Info Artikel \\
\hline Sejarah Artikel: \\
Diterima Oktober \\
2021 \\
Disetujui November \\
2021 \\
Dipublikasikan \\
November 2021 \\
\hline
\end{tabular}

Keywords: mufradât, antiradicalism, pocketbook, learning, Arabic

\begin{abstract}
Abstrak
Penelitian ini bertujuan untuk mengetahui dan mendeskripsikan pengembangan pocketbook untuk pembelajaran mufradât berbasis anti radikalisme bagi mahasiswa jurusan Pendidikan Bahasa Arab (PBA) FTIK IAIN Pekalongan. Penelitian pengembangan ini menggunakan model Analysis, Design, Development, Implementation, and Evaluation (ADDIE). Hasil penelitian menunjukkan: (1) Bentuk produk yang dihasikan berupa buku saku atau pocketbook mufradât berbasis anti radikalisme ukuran $11 \mathrm{~cm} \times 15 \mathrm{~cm}$ dengan jumlah 61 halaman. Pada bagian pertama berisi pendahuluan, bagian kedua isi materi, mufradât berbasis anti radikalisme dan pada halaman terakhir berisi daftar pustaka. Buku ini dibuat secara praktis dan menarik untuk memudahkan pengguna dan tidak membosankan bagi mahasiswa. Media pocketbook ini dapat diperbanyak dengan mudah sehingga setiap mahasiswa bisa memiliki secara pribadi; (2) Berdasarkan penilaian para ahli dapat disimpulkan bahwa, media pocketbook ini layak untuk digunakan dalam pembelajaran mufradât. Ahli materi memberikan nilai 71 hasil tersebut masuk dalam kategori "Sangat Layak" atau sangat baik sedangkan ahli media memberikan nilai 67 hasil tersebuat masuk dalam kategori "Layak" atau baik. Hasil angket mahasiswa terhadap penilaian pocketbook sebagai media pembelajaran mufradât mendapatkan nilai 79,95 masuk dalam kategori "Sangat Layak" atau Sangat Baik.
\end{abstract}

\section{Abstract}

This research aims to find out and describe the development of pocketbooks for Arabic vocabulary learning (mufradât) based on anti-radicalism for students majoring in Arabic Language Education (PBA) FTIK IAIN Pekalongan. This study's results are expected to make a real contribution to the advancement or development of Arabic vocabulary learning media (mufradât) based on anti-radicalism and add scientific insight into the development of Arabic vocabulary learning media (mufradât) based on anti-radicalism. This development research uses analysis, design, development, implementation, and evaluation (ADDIE) models. The results showed: (1) The resulting product form in the form of pocketbook Arabic vocabulary (mufradât) based on anti-radicalism size $11 \mathrm{~cm} \mathrm{x} 15 \mathrm{~cm}$ with a total of 61 pages. The first section contains an introduction (foreword and table of contents), the second part of the material's content, the Arabic vocabulary (mufradât) based on anti-radicalism, and the last page a list of libraries. This book is made practically and interestingly to make it easier for users and not dull for students. This pocketbook media can be reproduced easily so that every student can have it personally; (2) Based on the assessment of experts, it can be concluded that this pocketbook medium is worthy of use in Arabic vocabulary (mufradât). The material expert rated the results 71 in the category of "Very Worthy" or very good, while the media expert rated the 67 products in the category "Worthy" or acceptable. The student questionnaire results on the assessment of pocketbooks as a medium of Learning Arabic received a score of 79.95 in the category of "Very Worthy" or Very Good. 


\section{PENDAHULUAN}

Dalam proses pembelajaran bahasa Arab di jurusan Pendidikan Bahasa Arab (PBA), terdapat permasalahan klasik yang selalu dihadapi oleh mahasiswa jurusan Pendidikan Bahasa Arab (PBA), yaitu kurangnya kemampuan mahasiswa menguasai mufradât bahasa Arab. Mufradât merupakan salah satu unsur bahasa yang harus dimiliki dan dikuasai oleh pembelajar bahasa asing termasuk bahasa Arab. Perbendaharaan mufradât yang memadai dapat menunjang seseorang dalam berkomunikasi dan menulis dengan bahasa tersebut. Dengan demikian, dapat dikatakan bahwa berbicara dan menulis yang merupakan kemahiran berbahasa harus didukung oleh pengetahuan dan penguasaan mufradât yang kaya. Penambahan mufradât seseorang secara umum dianggap bagian penting, baik dari proses pembelajaran suatu bahasa ataupun pengembangan kemampuan seseorang dalam suatu bahasa yang sudah dikuasai (Warda Nor Fitriani, dkk 2015).

Selain permasalahan kurangnya penguasaan mufradât, permasalahan lainnya muncul adalah terkait dengan kurangnya pemahaman yang baik terhadap mufradât berbasis radikalisme yang mengatasnamakan agama. Hal ini lagi marak berkembang dan dikhawatirkan mahasiswa terpapar begitu jauh dengan paham radikalisme ini. Salah satu penyebabnya menurut Fealy dan Hooker, adalah akibat terbukanya kran demokratisasi yang telah menjadi lahan subur tumbuhnya kelompok Islam radikal pasca reformasi (Greg Fealy dan Virginia Hooker (ed.): 2006).

Radikalisme yang berujung pada terorisme menjadi masalah penting bagi umat Islam Indonesia dewasa ini. Dua isu itu telah menyebabkan Islam dicap sebagai agama teror dan umat Islam dianggap menyukai jalan kekerasan suci untuk menyebarkan agamanya. Sekalipun anggapan itu mudah dimentahkan, namun fakta bahwa pelaku teror di Indonesia adalah seorang muslim garis keras yang dampaknya sangat membebani psikologi umat Islam secara keseluruhan (Abu Rokhmad: 2012).

Yusuf al-Qardhawi mengatakan bahwa faktor utama munculnya radikalisme dalam beragama adalah kurangnya pemahaman yang benar dan mendalam atas esensi ajaran agama Islam itu sendiri dan pemahaman literalistik atas teks-teks agama (Yusuf al-Qardhawi: 2001). Arkoun dalam tulisannya menyatakan bahwa Al-Qur'an telah digunakan muslim untuk mengabsahkan perilaku, menjustifikasi tindakan peperangan, melandasi berbagai apresiasi, memelihara berbagai harapan, dan memperkukuh identitas kolektif (Mohammed Arkoun: 1997). Kurangnya pemahaman literalistik atas teks-teks agama yang terdapat dalam ayat-ayat Al-Qur'an menandakan ada permasalahan memaknai tiap mufradât bahasa Arab yang bermuatan radikalisme khususnya aya-ayat jihad dan perang (Dede Rodin: 2016). Dengan demikian, pemahaman yang tepat dan benar tentang mufradât setidaknya bisa menangkal berkembangnya paham radikalisme di tengah-tengah umat.

Mengingat sangat penting dan krusialnya kedudukan bahasa dalam mempengaruhi pemahaman seseorang. Maka, penguatan bahasa dalam kegiatan pembelajaran, menjadi salah satu potensi yang perlu dikembangkan di kalangan mahasiswa. Gardner mengungkapkan bahwa bahasa menjadi salah satu bagian dari teori kecerdasan majemuk yang merupakan kemampuan untuk berpikir dalam bentuk katakata dan menggunakan bahasa untuk mengekspresikan dan menghargai makna yang kompleks ketika seseorang berkomunikasi dengan orang lain, sehingga bahasa dapat dikatakan sebagai jembatan penghubung seseorang kepada orang lain baik dalam berkomunikasi, berinteraksi dan mengutarakan apa yang ingin disampaikan, dalam hal ini komunikasi yang dilakukan antara mahasiswa sebagai penerima pesan pembelajaran dan dosen selaku pemberi informasi (Siti Rohmah: 2008).

Selain itu, bahasa Arab juga mempunyai tatanan gramatika yang tidak mudah dan berbedabeda sesuai kaidah nahwu yang ada. Ada yang memiliki pola kalimat yang diawali dengan kata benda, yang disebut dengan jumlah ismiyah. Ada juga pola kalimat yang diawali dengan kata kerja, yang disebut dengan jumlah fi'liyah. Oleh karena itu, penguasaan mufradât sangat perlu dan penting. Hal itu dapat membantu dan memudahkan mahasiswa dalam mencapai kemampuan berbahasa, baik menyimak, berbicara, membaca maupun menulis. Maka pembelajaran mufradât perlu dikaji lebih mendalam.

Upaya yang dapat dilakukan untuk permasalahan di atas adalah dengan mengembangkan sebuah pocketbook (buku saku) untuk pembelajaran mufradât berbasis anti radikalisme yang mudah dipahami dan gampang dibawa oleh mahasiswa. Hal ini merupakan salah satu alternatif yang menarik bagi mahasiswa dimana mahasiswa juga bisa langsung terlibat dalam proses pembuatan buku saku tersebut. 


\section{METODE PENELITIAN}

Penelitian ini merupakan penelitian dan pengembangan (Research and Development) menggunakan model yang dikembangkan oleh Dick and Carry. Prosedur penelitian yang digunakan dalam penelitian dan pengembangan ini menggunakan model ADDIE yang dikembangkan oleh Dick and Carry dalam Sugiyono yang meliputi 5 tahap sebagai berikut (Sugiyono:2015):

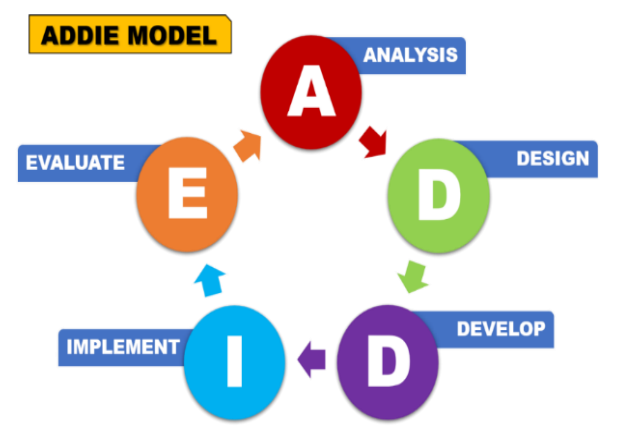

Gambar 1. Prosedur Pengembangan Media PocketBook Model ADDIE

Tahap pertama, yaitu tahap analisis (analysis). Pada tahap ini, kegiatan utama adalah menganalisis perlunya pengembangan model/metode pembelajaran baru. Tujuan pada tahap analisa adalah untuk mengumpulkan berbagai informasi yang relevan dengan pengembangan produk media pocketbook untuk pembelajaran mufradāt berbasis anti radikalisme bagi mahasiswa jurusan Pendidikan Bahasa Arab (PBA) FTIK IAIN Pekalongan. Informasi untuk analisis kebutuhan ini berasal dari studi lapangan dan studi pustaka.

Tahap kedua, yaitu tahap perancangan (design). Pada tahap ini, dilakukan perancangan atau perencanaan media pocketbook. Kegiatan ini merupakan proses sistematik yang dimulai dari menetapkan tujuan belajar, merancang skenario, atau kegiatan belajar mengajar, merancang perangkat pembelajaran, merancang materi pembelajaran dan alat evaluasi hasil belajar.

Tahap ketiga, yaitu tahap pengembangan (development). Development dalam model ADDIE berisi kegiatan realisasi rancangan produk. Dalam pembuatan media pocketbook yang diawali dengan design, pencetakan dan penjilidan, peneliti juga diharapkan mampu melakukan penyuntingan dan mengkonsultasikan dengan ahli media atau ahli materi bahasa Arab atau praktisi pembelajaran bahasa Arab, kemudian divalidasi oleh dosen ahli yaitu ahli materi dan ahli media yang merupakan dosen yang ahli dalam bidang bahasa Arab dan ahli media. Hal ini bertujuan agar mendapat produk pocketbook yang layak digunakan dan untuk menyempurnakan produk. Dengan adanya proses penyuntingan maka akan terhindar dari kesalahan-kesalahan baik konsep maupun bahasa. Berdasarkan hasil penyuntingan dilakukan revisi. Revisi dilakukan seperlunya berdasarkan dari hasil rekomendasi para ahli.

Tahap keempat, yaitu tahap implementasi (implementation). Pada tahap ini rancangan dan metode yang telah dikembangkan diimplementasikan pada situasi yang nyata yaitu, di kelas. Tujuannya adalah untuk mengetahui respon mahasiswa terhadap media pocketbook. Uji coba lapangan dilakukan seperti situasi proses pembelajaran melibatkan dosen dan mahasiswa jurusan Pendidikan Bahasa Arab (PBA) FTIK IAIN Pekalongan semester IV Tahun Akademik 2019/2020.

Tahap kelima, yaitu tahap evaluasi. Pada tahap ini, dilakukan evaluasi terhadap produk pocketbook secara keseluruhan sebelum menjadi produk akhir. Tahap ini dijadikan dasar untuk meningkatkan kualitas produk dikemudian hari. Adapun langkah-langkah yang ditempuh dalam tahap evaluasi ini yaitu:

a. Memberikan angket penilaian tanggapan mahasiswa atau respon kepada mahasiswa untuk memberikan tanggapan tentang media pocketbook.

b. Analisis hasil angket yang telah dibagikan untuk menyempurnakan produk sebelum disebarluaskan.

\section{HASIL PEMBAHASAN}

Dalam penelitian pengembangan media pocketbook untuk pembelajaran mufradât berbasis anti radikalisme, peneliti menggunakan tahaptahap yang terdiri dari 5 tahap, yaitu: 


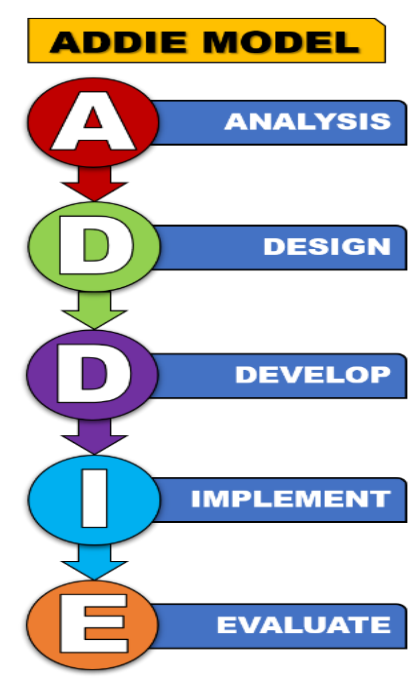

\section{Gambar 2. Pengembangan Media Pocket Book Model ADDIE}

\section{Tahap Analisis (Analysis)}

Pada tahap analisis, peneliti melakukan observasi yang dirangkum sebagai berikut.

\section{a. Analisis Situasi dan Keadaan}

Pada observasi awal ini juga, diamati belum adanya buku pegangan yang digunakan dosen dan mahasiswa tentang mufradât. Hal ini disebabkan karena masih terbatasnya modul/bahan ajar yang disusun sendiri oleh dosen sebagai panduan dalam mengajar. Karena itu, peneliti berasumsi bahwa mahasiswa akan merasa bersemangat dan membantu meningkatkan kemampuan mufradât mahasiswa yang ditunjang dengan bahan ajar yang disusun untuk mahasiswa.

\section{b. Analisis Pustaka}

Berdasarkan analisis pustaka, peneliti menelaah kurikulum dan mengkaji referensireferensi yang sesuai dengan kebutuhan mahasiswa untuk mata kuliah Al-Mufradāt.

\section{c. Merumuskan tujuan}

Berdasarkan analisis terhadap kurikulum yang digunakan, memberikan informasi bahwa materi yang dapat dikembangkan sesuai dengan silabus yang digunakan. Selanjutnya, jika dilihat pada aspek tujuan media pocketbook ini dibuat oleh peneliti diharapkan mampu memenuhi kebutuhan mahasiswa jurusan Pendidikan Bahasa Arab (PBA) FTIK IAIN Pekalongan yaitu tersedianya buku referensi yang menarik, praktis, dan mudah dipahami mahasiswa, sehingga pocketbook layak sebagai media pembelajaran mahasiswa dalam mempelajari bahasa Arab.

\section{Tahap Perancangan (Design)}

Pada tahap kedua ini, silabus akan mendasari proses pengembangan rancangan pocketbook. Peneliti akan mengelola data dari analisis awal sehingga menghasilkan:

\section{a. Rancangan produk}

Pocketbook yang dirancang praktis dengan tampilan yang menarik dan isi serta bahasa yang mudah dipahami. Terdapat mufradât sesuai tema dan materi yang diambil dari beberapa ayat Al-Qur'an dan Hadis tentang radikalisme. Peneliti memilih materi dari kitab Syifãiul Ummah karya KH. Taufiqul Hakim, jilid pertama, memuat topik "Menangkal Hal Radikal", beberapa sumber online (jurnal) dan beberapa kamus baik online ataupun offline (kamus online yang beralamat di www.almaany.com dan kamus offline seperti kamus Munawir, kamus Lisanul Arab) yang dijadikan sebagai bahan referensi penyusunan pocketbook mufradât berbasis anti radikalisme.

Berdasarkan tahap pertama yaitu analisis, maka diperoleh rancangan produk pocketbook sebagai berikut: 
Tabel 3. Desain Media Pembelajaran berbentuk Pocketbook

\begin{tabular}{|c|c|c|}
\hline No. & Desain & Keterangan \\
\hline 1 & Bentuk Fisik & $\begin{array}{l}\text { Buku dengan ukuran kertas } 11 \mathrm{~cm} \times 15 \mathrm{~cm} \\
\text { dan setak warna bergambar. }\end{array}$ \\
\hline 2. & Materi & $\begin{array}{l}\text { Renulisan mufradet urut mengikuti tema } \\
\text { materi bahasan, }\end{array}$ \\
\hline 3. & Bahasa & $\begin{array}{l}\text { Arab (isj kosakata) dan Indonesia } \\
\text { (pendahuluan dan penjelasan) }\end{array}$ \\
\hline & Bagian & 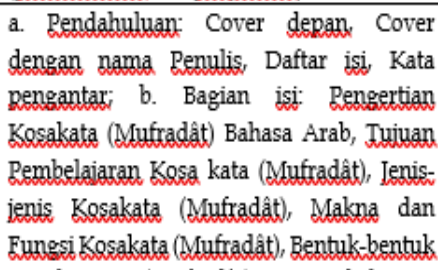 \\
\hline & & Sossakata (Mufradât), Rembelajaran. \\
\hline & & Kossakata (Mufradât), Dasar-dasar \\
\hline & & Remilihan Kosakata (Mufradât), Pembagian \\
\hline & & Mufradât Bahasa Arab, Karakata \\
\hline & & $\begin{array}{l}\text { (Mufradât) Radikalisme; c. Penutup; Daftar } \\
\text { Pustaka. }\end{array}$ \\
\hline & Fungsi & $\begin{array}{l}\text { Sebagai media pembelaiaran secara mandiri } \\
\text { baik di kelas maunun di luar kelas. }\end{array}$ \\
\hline
\end{tabular}

a) Penjelasan awal tentang: Pengertian Kosakata (Mufradât) Bahasa Arab, Tujuan Pembelajaran Kosa kata (Mufradât), Jenis-jenis Kosakata (Mufradât), Makna dan Fungsi Kosakata (Mufradât), Bentuk-bentuk Kosakata (Mufradât), Pembelajaran Kosakata (Mufradât), Dasar-dasar Pemilihan Kosakata (Mufradât), Pembagian Mufradât Bahasa Arab, Kosakata (Mufradât) Radikalisme.

b) Penyajian kosakata-kosakata (mufradât) berbasis anti radikalisme sesuai materi yang bersumber dari beberapa ayat Al-Qur'an dan Hadis tentang isu-isu anti radikalisme berdasarkan isi kitab Syifãiul Ummah karya KH. Taufiqul Hakim, jilid pertama, dengan topik Menangkal Hal Radikal, disajikan dalam pocketbook dan dilengkapi penjelasan arti dan makna kosakata (mufradât) berbasis anti radikalisme untuk memudahkan memahami materi.
Pada tahap kedua ini, draft pocketbook dibuat dengan proses sebagai berikut:

1) Mufradât sesuai materi dalam pocketbook dari kitab Syifãiul Ummah karya KH. Taufiqul Hakim, jilid pertama, dengan topik "Menangkal Hal Radikal" dan disesuaikan pada kebutuhan.

2) Peneliti menyusun materi untuk disajikan dalam pocketbook menggunakan aplikasi Microsoft Word 365 dan Corel Draw 2019.

3) Tahap akhir dalam penyusunan buku saku adalah mengubahnya ke dalam format PDF.

4) Pencetakan buku saku / pocketbook sejumlah responden.

Secara umum, bagian-bagian dalam pocketbook dapat dijelaskan sebagai berikut:

1) Bagian Pendahuluan

a) Cover depan, cover dengan nama penulis, kata pengantar berisi keterangan (uraian) sebagai pengantar diterbitkannya pocketbook.

b) Daftar isi berisi petunjuk pokok isi dalam pocketbook serta nomor halaman.
3) Bagian Penutup

a). Daftar Pustaka.

b) Susunan Materi Pocket Book

a) Hasil identifikasi isi materi kitab Syifãiul Ummah

2) Bagian Isi 
Jauhar Ali / Journal of Arabic Learning and Teaching 10 (2) (2021)

Tabel 4. Hasil identifikasi isi materi

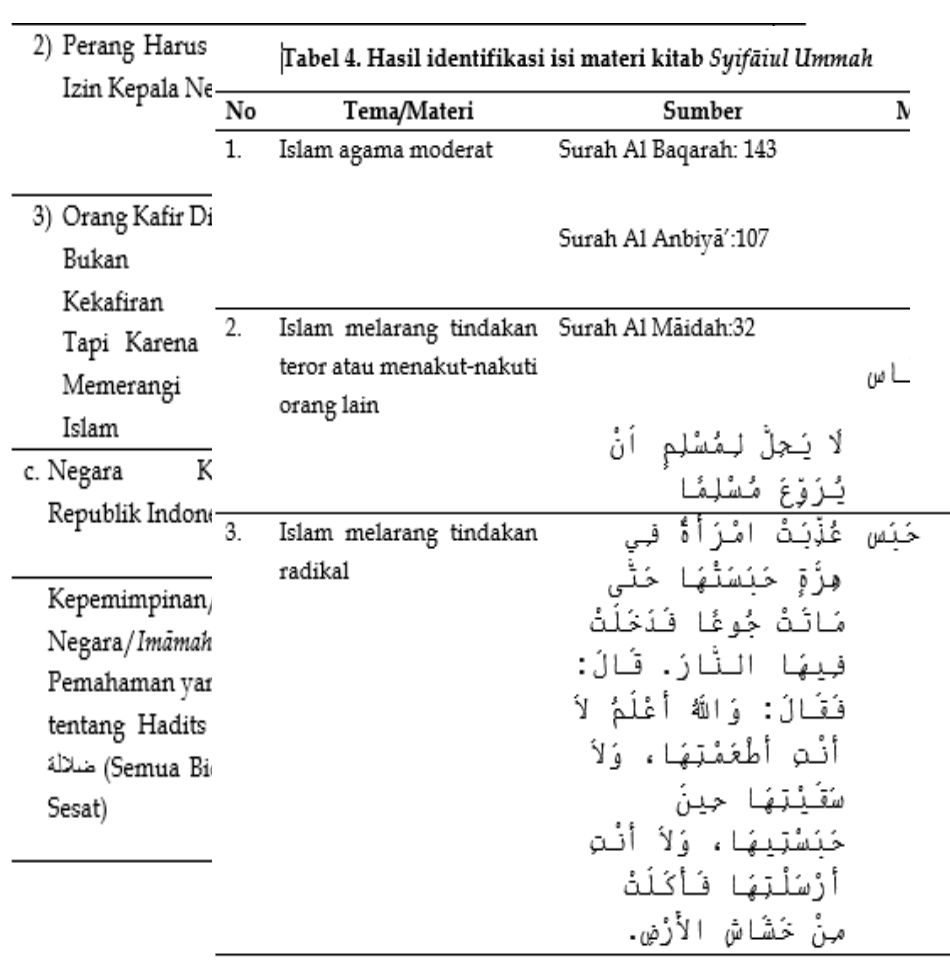

\begin{tabular}{|c|c|c|}
\hline $\begin{array}{l}\text { Hadits Nabi Muhammad } \\
\text { SAW yang melaknat } \\
\text { orang yang menjadikan } \\
\text { makhluk bernyawa } \\
\text { sebagai sasaran tembak }\end{array}$ & 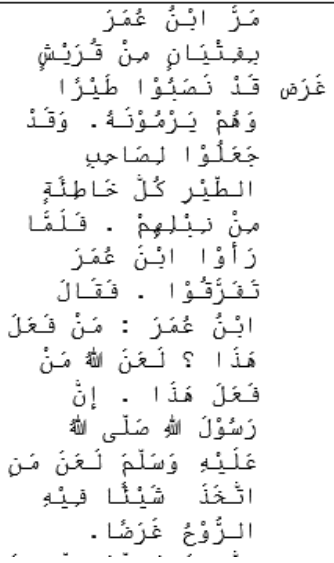 & 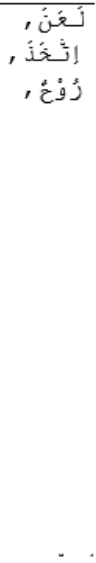 \\
\hline
\end{tabular}

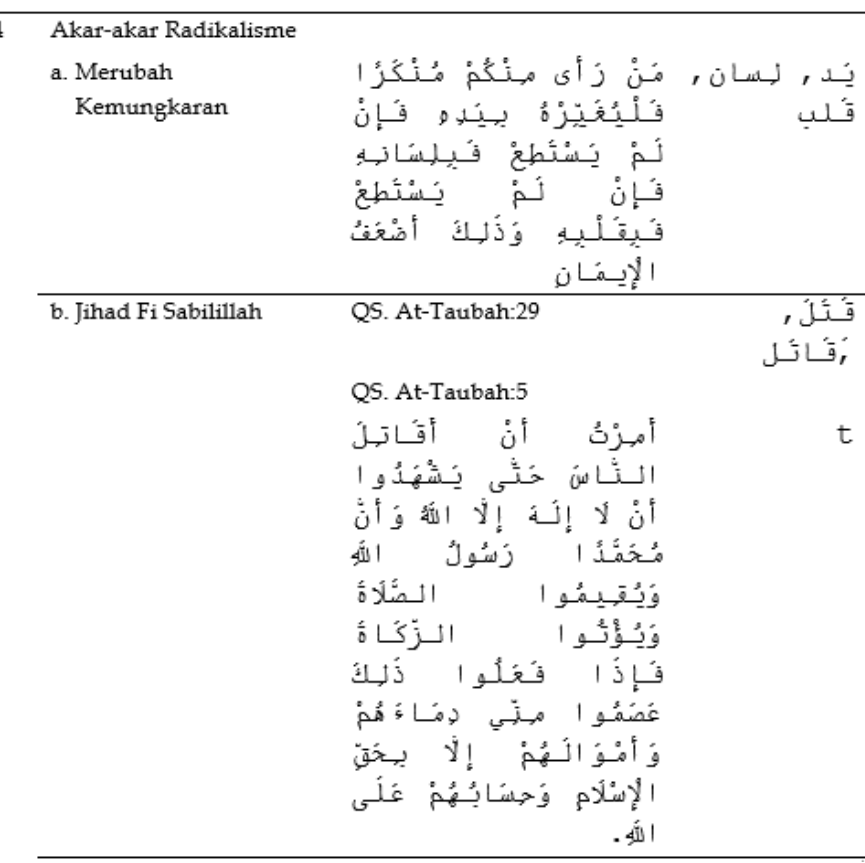

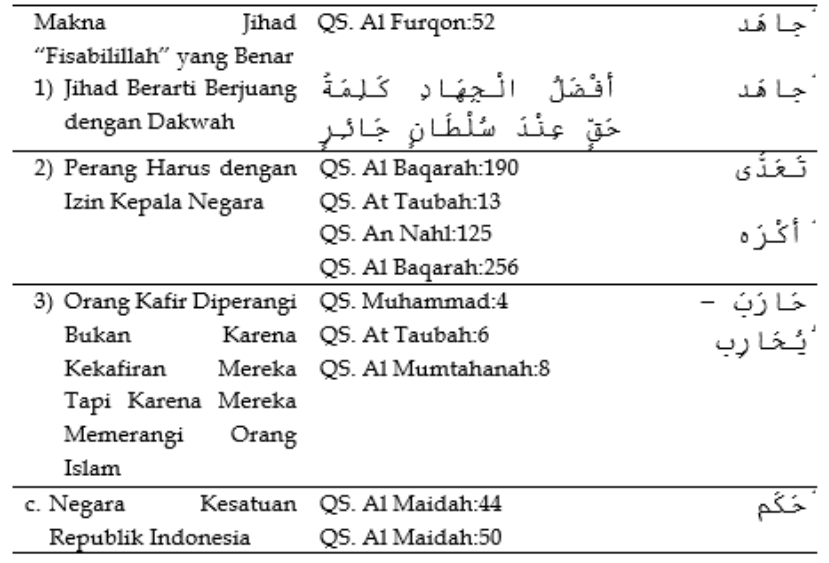

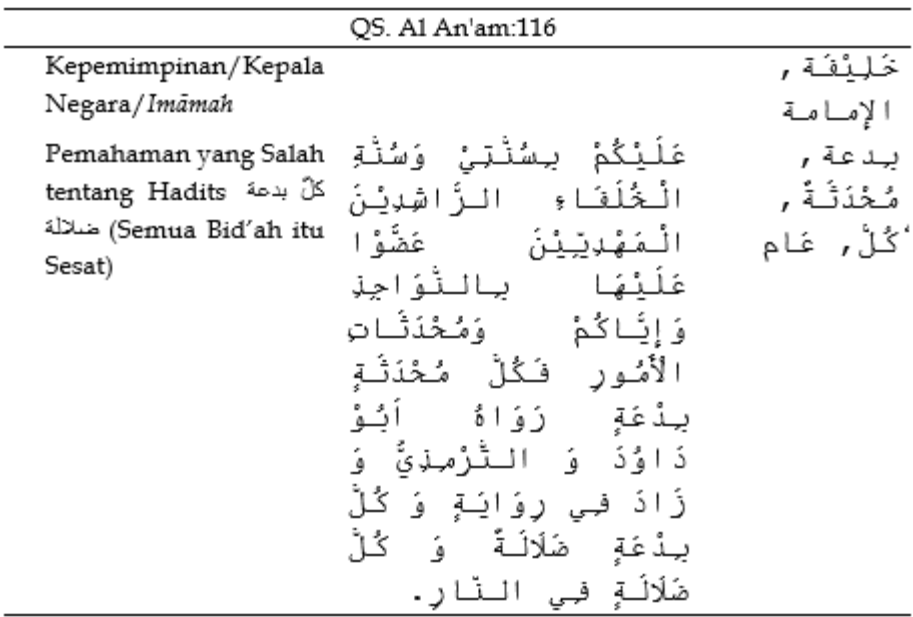

b) Pembuatan Flowchart 


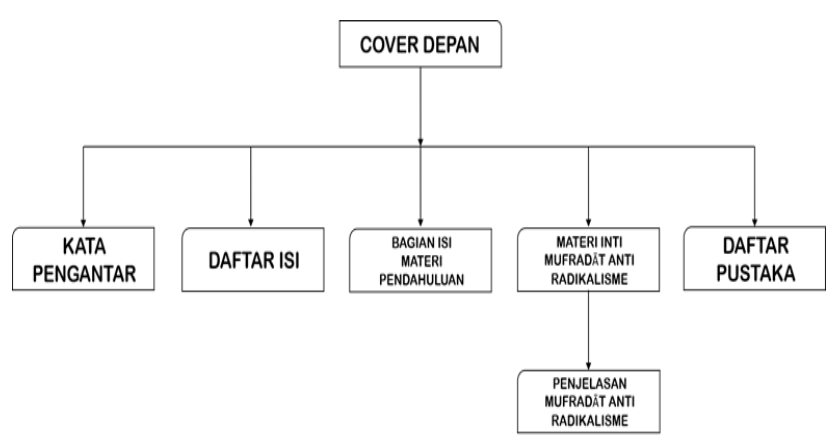

c) Pembuatan Storyboard

1) Cover Depan

2) Cover Dalam
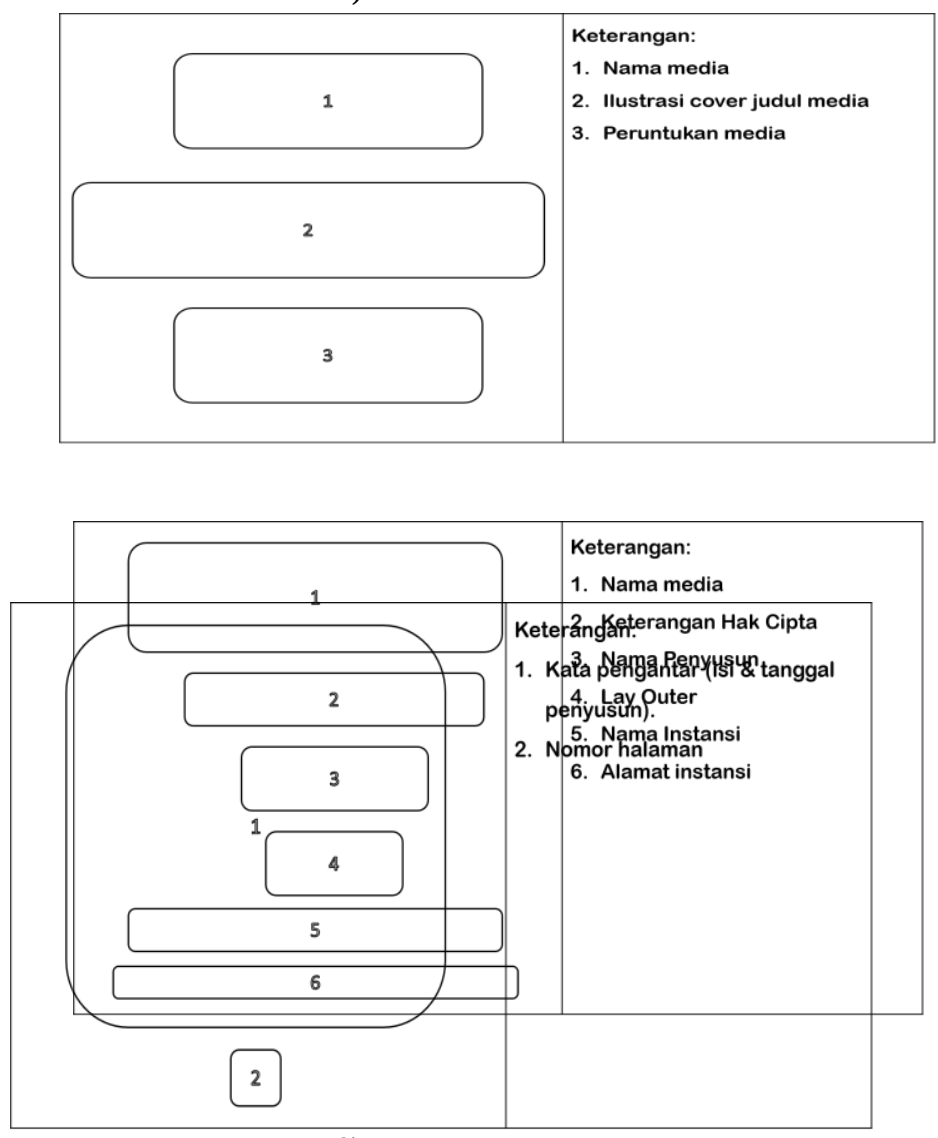

3) Kata Pengantar

4) Daftar Isi

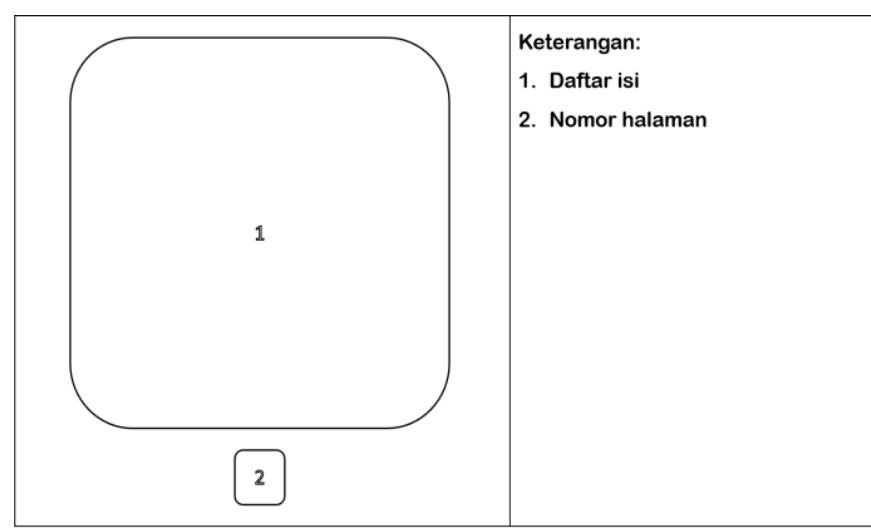

5) Bagian Isi: Materi Pendahuluan

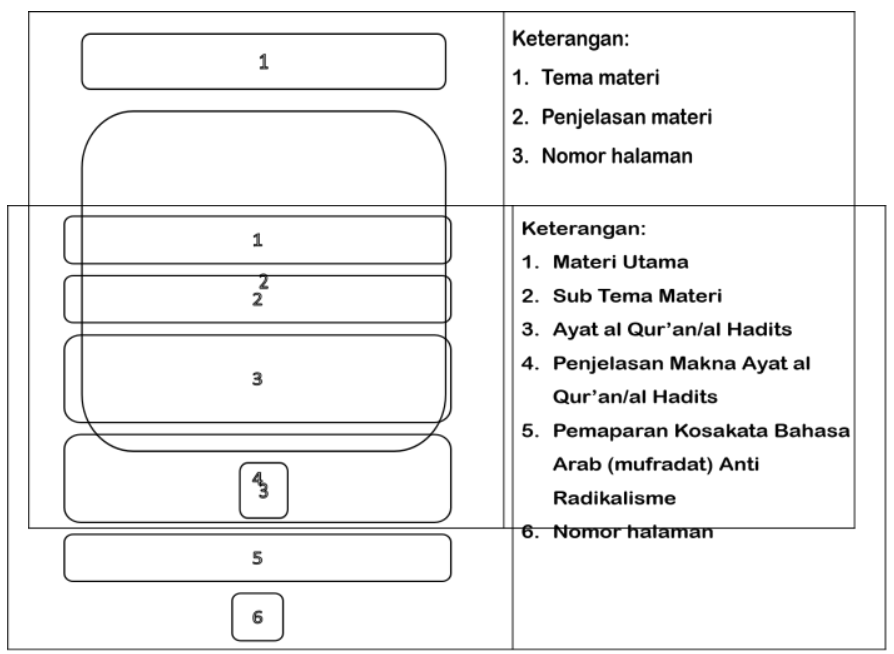

6) Materi Inti: Mufradat Anti Radikalisme

7) Daftar Pustaka

\section{3) Tahap Pengembangan (Development)}

\section{a. Pembuatan Draft Pocket Book}

Pada tahap pengembangan ini pocketbook akan diproduksi untuk digunakan dalam proses pembelajaran. Materi

Tabel 5. Hasil Validasi Pocket Book oleh Ahli Materi

\begin{tabular}{cccc}
\hline Tahap & $\begin{array}{c}\text { Jumlah Skor } \\
\text { Yang Diperoleh }\end{array}$ & $\begin{array}{c}\text { Skor } \\
\text { Maksimum }\end{array}$ & Kategori \\
\hline $\begin{array}{c}1 \\
2\end{array}$ & 71 & 90 & Sangat Layak \\
\hline & & & \\
\hline & & & \\
\hline
\end{tabular}


berdasarkan silabus, cover dan bagian isi didesain menggunakan aplikasi Corel Draw 2019 dengan pemilihan warna yang didasarkan atas kajian ilmiah.

\section{b. Pembuatan Instrumen Penilaian Pocket Book Mufradât}

Instrumen penilaian pocketbook mufradât menggunakan angket yaitu angket kelayakan produk. Angket penilaian produk diambil dari Instrumen Penilaian Buku Teks Pelajaran Tahun 2014 yang dikeluarkan oleh Badan Standar Nasional Pendidikan (BSNP). Instrumen berupa angket kelayakan produk dugunakan untuk proses ujicoba produk.

\section{c. Validasi Kelayakan Pocket Book}

Data yang dikumpulkan dalam penelitian ini adalah data kuantitatif berupa skor dan data kualitatif berupa kategori. Validasi pocketbook dilakukan oleh ahli materi dan ahli media.

\section{1) Validasi Ahli Materi}

Ahli materi pada penelitian ini adalah salah satu dosen Jurusan Pendidikan Bahasa Arab (PBA) FTIK IAIN Pekalongan. Validasi dilakukan terkait dengan aspek kelayakan isi dan kelayakan kebahasaan dari pocketbook yang dikembangkan dengan rentang skala penilaian 1-5. Selain memberikan penilaian dari segi materi, ahli materi juga memberikan saran dan komentar untuk perbaikan media. Berikut merupakan hasil validasi ahli materi.

Berdasarkan tabel di atas, peneliti memperoleh hasil skor validasi materi sebesar 71 sehingga hal ini dapat menyimpulkan bahwa materi masuk kategori "Sangat Layak" atau sangat baik untuk digunakan atau diujicobakan di lapangan dengan revisi dan saran ahli materi.

\section{2) Validasi Ahli Media}

Ahli media pada penelitian ini adalah dari salah satu dosen jurusan Pendidikan Bahasa Arab (PBA) FTIK IAIN Pekalongan. Validasi dilakukan terkait dengan aspek kelayakan penyajian dan kegrafisan dari pocketbook yang dikembangkan. Angket yang digunakan berskala
1-5. Selain memberikan penilaian terhadap kelayakan media pocketbook, ahli media juga memberikan saran serta komentar untuk revisi media. Berikut merupakan hasil validasi ahli media.

Berdasarkan tabel di atas, peneliti memperoleh hasil skor validasi materi sebesar 67 sehingga hal ini dapat menyimpulkan bahwa materi masuk kategori "Layak" atau baik untuk digunakan atau diujicobakan di lapangan dengan revisi dan saran ahli media.

\section{d. Revisi Kelayakan Produk}

\section{1) Revisi Ahli Materi}

Pada tahap ini dilakukan perbaikan pada produk sesuai kritik dan saran ahli materi untuk kelayakan produk.

Tabel 7. Hasil komentar dan Saran oleh Ahli Materi

\begin{tabular}{|c|c|c|c|}
\hline No. & Jenis Kesalahan & Komentar/saran & Tindak Lanjut \\
\hline 1. & 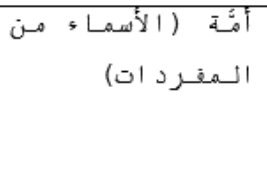 & $\begin{array}{l}\text { Penyajian dalam } \\
\text { kolom mufradöt, } \\
\text { disajikan dalam } \\
\text { bentuk ism nakirah }\end{array}$ & $\begin{array}{l}\text { Penulisan tiap } \\
\text { mufradät yang } \\
\text { berbentuk ism, } \\
\text { telah diperbaiki } \\
\text { sesuai saran ahli } \\
\text { materi }\end{array}$ \\
\hline 2. & 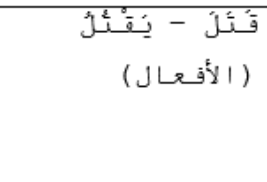 & $\begin{array}{l}\text { Tashrif kata kerja } \\
\text { (fi'l), disajikan } \\
\text { dalam susunan } \\
\text { yang lengkap dari } \\
\text { awal hingga akhir }\end{array}$ & $\begin{array}{l}\text { Perubahan tiap } \\
\text { kata kerja telah } \\
\text { disajikan secara } \\
\text { detil sesuai saran } \\
\text { ahli materi }\end{array}$ \\
\hline
\end{tabular}

Tabel 8. Materi mufradāt sebelum diperbaiki

\begin{tabular}{|c|c|c|}
\hline Kosakata & \multicolumn{2}{|c|}{ Teriemahan } \\
\hline 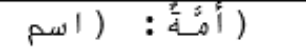 & \multicolumn{2}{|c|}{ ummat } \\
\hline 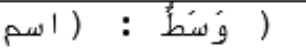 & \multicolumn{2}{|c|}{ di antara } \\
\hline 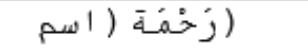 & \multicolumn{2}{|c|}{ rahmat } \\
\hline (عاكَ لَم ( اسم & \multicolumn{2}{|c|}{ Alam } \\
\hline 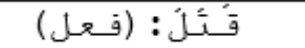 & \multicolumn{2}{|c|}{ membunuh } \\
\hline 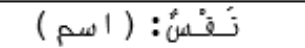 & \multicolumn{2}{|l|}{ jiwa } \\
\hline \multirow[t]{2}{*}{ تَّان } & \multicolumn{2}{|c|}{ manusia } \\
\hline & $\begin{array}{l}\text { gambar yang } \\
\text { mewakili tema }\end{array}$ & $\begin{array}{l}\text { di sesuaikan di } \\
\text { media sesuai } \\
\text { masukan ahli }\end{array}$ \\
\hline 4. Ukuran pada Halaman & $\begin{array}{l}\text { Nomer halaman } \\
\text { kurang }\end{array}$ & $\begin{array}{l}\text { Ukuran angka } \\
\text { pada halaman } \\
\text { sudah di }\end{array}$ \\
\hline
\end{tabular}


Hasil perbaikan sesuai saran ahli, sebagai berikut:

2) Revisi Ahli Media

Pada tahap ini dilakukan perbaikan pada produk sesuai kritik dan saran ahli media untuk kelayakan produk.

\section{4) Tahap Implementasi (Implementation)}

Tabel 9. Materi mufradāt setelah diperbaiki

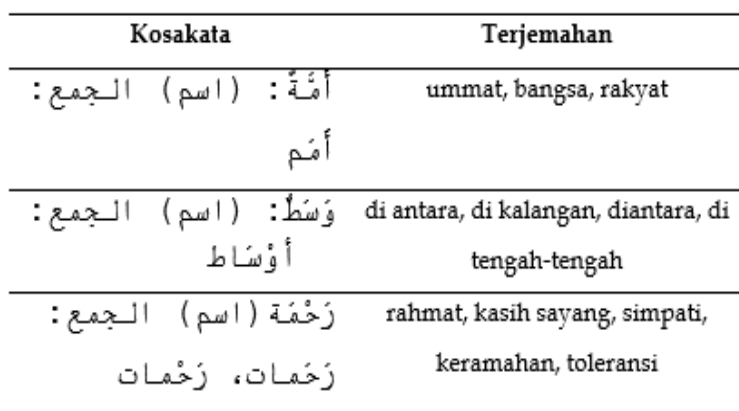

Pada tahap ini, media pocketbook yang dikembangkan akan diujicobakan pada uji coba lapangan di mahasiswa. Pocketbook yang digunakan untuk uji coba lapangan merupakan hasil revisi dan perbaikan menurut saran dari para ahli materi dan ahli media. Uji coba lapangan dilakukan kepada 24 mahasiswa kelas C Pendidikan Bahasa Arab (PBA) FTIK IAIN Pekalongan semester IV Tahun Akademik 2019/2020. Pelaksanaan uji coba pada tanggal 21 Oktober 2019. Peneliti mengajar menggunakan pocketbook mufradât sebagai media pendukung. Di akhir pertemuan, mahasiswa melakukan penilaian terhadap pocketbook. Validasi dilakukan terkait dengan aspek isi, kebahasaan, penyajian, dan kegrafisan. Angket yang digunakan berisi 18 butir pertanyaan menggunakan skala 1-5.

\section{5) Tahap Evaluasi (Evaluation)}

Pada tahap evaluasi dilakukan pengukuran kelayakan media pocketbook secara keseluruhan oleh 24 mahasiswa. Kelayakan media pocketbook pada pembelajaran mahasiswa dapat dilihat

Tabel 11. Hasil Angket Kelayakan Media Pocket Book

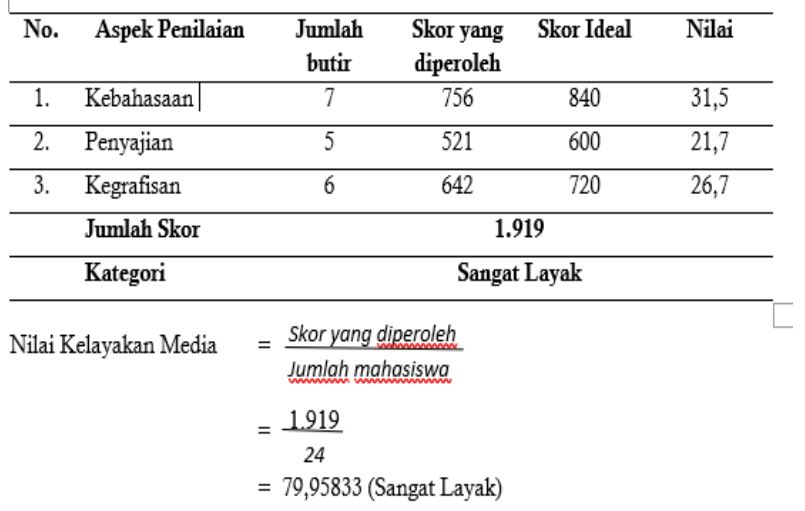

dari hasil angket mahasiswa dengan skala Likert. Skor kelayakan media setelah mahasiswa menggunakan

\begin{tabular}{|c|c|c|}
\hline & $\begin{array}{l}\text { jelas/kurang } \\
\text { besar. }\end{array}$ & $\begin{array}{l}\text { perbesar meniadi } \\
14 \text { dan letak } \\
\text { sudah } \\
\text { dipindahkan } \\
\text { sesuai saran ahli. }\end{array}$ \\
\hline 5. Font & $\begin{array}{l}\text { Urutan, ukuran } \\
\text { font berbagai } \\
\text { macam } 10,12 \\
\text { dan } 11 \text { sehingga } \\
\text { membuat tidak } \\
\text { teratur. }\end{array}$ & $\begin{array}{l}\text { Ukuran font yang } \\
\text { tidak teratur. } \\
\text { sudah durut dan } \\
\text { diubah menaiadi } \\
\text { 14,15 Dan } 16 \\
\text { Sesuai saran } \\
\text { ahli. }\end{array}$ \\
\hline 6. $\quad$ Daftar pustaka & $\begin{array}{l}\text { Sumber gambar } \\
\text { belum } \\
\text { disebutkan. }\end{array}$ & $\begin{array}{l}\text { Sumber gambar } \\
\text { sudah } \\
\text { ditambahkan } \\
\text { pada halaman } \\
\text { penutup. }\end{array}$ \\
\hline 7. Materi & $\begin{array}{l}\text { Urutan saijan } \\
\text { materi (isi) } \\
\text { belum konsisten. }\end{array}$ & $\begin{array}{l}\text { Materi sudah } \\
\text { diurutkan sesuai } \\
\text { saran ahli. }\end{array}$ \\
\hline
\end{tabular}

pocketbook, sebagai berikut:

Skor kelayakan media setelah mahasiswa menggunakan pocketbook setelah melakukan perhitungan mendapat 79,95833 dirata-rata menjadi 79,95. Sesuai tabel 2. Kategori Kelayakan pada bab III, skor tersebut memasuki kategori "Sangat Layak". Kesimpulannya, berdasarkan perhitungan skor rata-rata, menunjukkan bahwa media pocketbook yang digunakan, 
terbukti layak sebagai media pembelajaran mufradât.

\section{Simpulan}

Berdasarkan hasil penelitian
pengembangan dan pembahasan, dapat
disimpulkan bahwa: Bentuk produk yang
dihasikan berupa buku saku atau pocketbook
kosakata bahasa Arab (mufradât) berbasis anti
radikalisme ukuran $11 \mathrm{~cm} \times 15 \mathrm{~cm}$ dengan jumlah
61 halaman. Pada bagian pertama berisi
pendahuluan (kata pengantar dan daftar isi),
bagian kedua isi materi, kosakata bahasa Arab
(mufradât) berbasis anti radikalisme dan pada
halaman terakhir berisi daftar pustaka. Buku ini
dibuat secara praktis dan menarik untuk
memudahkan pengguna dan tidak membosankan
bagi mahasiswa. Media pocketbook ini dapat
diperbanyak dengan mudah sehingga setiap
mahasiswa bisa memiliki secara pribadi.

Berdasarkan penilaian dari para ahli dapat disimpulkan bahwa, media pocketbook ini layak untuk digunakan dalam pembelajaran kosakata bahasa Arab (mufradât). Ahli materi memberikan nilai 71 hasil tersebut masuk dalam kategori "Sangat Layak" atau sangat baik sedangkan ahli media memberikan nilai 67 hasil tersebuat masuk dalam kategori "Layak" atau baik. Hasil angket mahasiswa terhadap penilaian pocketbook sebagai media pembelajaran bahasa Arab mendapatkan nilai 79,95 masuk dalam kategori "Sangat Layak" atau Sangat Baik.

\section{DAFTAR PUSTAKA}

Abdurrahman, D. (2003). Pengantar Metode Penelitian. Yogyakarta: Kurnia Kalam Semesta.

Anggraeni, Yuli. (2016). Pengembangan Media Pembelajaran Berbentuk Pocket Book Untuk Meningkatkan Motivasi Belajar Siswa pada Mata Pelajaran Praktik Akuntansi Manual (PAM) Kelas XI Akuntansi. Diakses dari eprints.uny.ac.id pada tanggal 28 September 2018.

Ania, Yayi. (2017). Pengaruh Penggunaan Pocket Book Terhadap Hasil Belajar Fisika Siswa SMA. Diakses dari repository.uinjkt.ac.id pada tanggal 4 Januari 2019.

Arifin, Winarsih, dkk. (2004). Kamus PrancisIndonesia. Jakarta : Gramedia Pustaka Utama.

Arsyad, Azhar. (2016). Media Pembelajaran. Jakarta: PT. Raja Grafindo Persada.

al-Qardhawi, Y. (2001). as-Sâhwah al-Islâmiyyah bayna al-Juhûd wa at-Tatarruf. Kairo: Dâr asy-Syurûq.

Arikunto, S. (1995). Manajemen Penelitian. Jakarta: Rieneka Cipta.

Arkoun, M. (1997). Berbagai Pembacaan alQur'an. Jakarta: INIS.

Brown, H. D. (2008). Prinsip Pembelajaran dan Pengajaran Bahasa. Jakarta: Kedutaan Besar Amerika.

Departemen Pendidikan Nasional. (2012). Kamus Besar Bahasa Indonesia Pusat Bahasa Edisi Keempat. Jakarta: Gramedia Pustaka Utama.

Dimyati. (1999). Belajar dan Pembelajaran. Jakarta: Rineka Cipta.

Daryanto. (2013). Media Pembelajaran. Yogyakarta: Gava Media.

Effendy, Ahmad Fuad . (2017). Metodologi Pengajaran Bahasa Arab. Malang: Misykat.

Greg Fealy, V. H. (2006). Voices of Islam in Southeast Asia: a Contemporary Sourcebook. Singapore: ISEAS.

Hakim, L. (2005). Pengantar Kata Pengantar dalam Islam dan Radikalisme di Indonesia. Jakarta: LIPI Press.

Indriana, Dina. (2011). Ragam Alat Bantu Media Pengajaran. Yogyakarta: Diva Press.

Iskandarwassid dan Dadang Sunendar. (2013). Strategi Pembelajaran Bahasa. Bandung: PT. Remaja Rosda Karya. 
Kusumah, Wijaya. (2012). Sistematika Penulisan Karya Tulis Ilmiah. Diakses dari edukasi.kompasiana.com pada tanggal 5 januari 2019.

Kustandi, Cecep dan Sutjipto Bambang. 2013. Media Pembelajaran: Manual dan Digital. Bogor: Ghalia Indonesia.

Laisa, E. (2014). Islam dan Radikalisme. Islamuna: Jurnal Studi Islam, 1-3.

Laksita, S. V. (2013). Pengembangan Media Pembelajaran Fisika dalam Bentuk Pocket Book pada Materi Alat Optik Serta Suhu dan Kalor Untuk Kelas X SMA. Jurnal Materi dan Pembelajaran Fisika (JMPF), Vol. 3, No. 1.

Masduqi, I. (2012). Berislam Secara Toleran: Teologi Kerukunan Umat Beragama. Bandung: Mizan.

Masduqi, I. (2013). Deradikalisasi Pendidikan Islam Berbasis Khazanah Pesantren. Jurnal Pendidikan Islam, 2.

Mubarok, M. Z. (2007). Geneologi Islam Radikal di Indonesia: Gerakan, Pemikiran dan Prospek Demokrasi. Jakarta: Pustaka LP3ES Indonesia.

Mustofa, Syaiful. (2011). Strategi Pembelajaran Bahasa.

Mawardi, Dodi. (2007). Cara Mudah Menulis Buku. Jakarta: Niaga Swadaya.

Nababan, S. U. (1997). Metodologi Pengajaran Bahasa. Jakarta: Gramedia.

Rahmah, S. (2008). Teori Kecerdasan Majemuk Howard Gardner dan Pengembangannya pada Metode Pembelajaran Pendidikan Agama Islam untuk Anak Usia Sekolah Dasar. Jurnal Pendidikan Agama Islam, Vol. V, No. 1.

Rokhmad, A. (2012). Radikalisme Islam dan Upaya Deradikalisasi Paham Radikal. Walisongo, Vol. 20, No. 1.

Rodin, Dede. (2016). ISLAM DAN RADIKALISME: Telaah atas Ayat- ayat "Kekerasan" dalam al-Qur'an. ADDIN, Vol. 10, No. 1.

Sugiyono. (1999). Metode Penelitian Bisnis. Bandung: CV Alfa Beta.

Sukarjo. (2008). Evaluasi Pembelajaran. In P. U. Yogyakarta, Diktat Mata Kuliah Program Studi Teknologi Pembelajaran. Yogyakarta: PPs. Universitas Negeri Yogyakarta.

Sukmadinata, N. S. (2006). Metode Penelitian Pendidikan. Bandung: PT Remaja Rosdakarya.

Tarigan, H. G. (1986). Pengajaran Kosakata. Bandung: Angkasa.

Warda Nor Fitriani, S. W. (2015). Pengembangan Media Visual Flashcard Materi Pokok Kosa Kata Benda-benda di Ruang Makan Mata Pelajaran Bahasa Arab Kelas II MI Nurul Ulum Sidorejo Kebonsari Madiun. Jurnal Mahasiswa Teknologi Pendidikan, Vol. 6 No. 2.

Wulandari, N. (2018). Pengembangan Buku Saku Intensifikasi Bahasa Arab di IAIN Metro dengan Menggunakan Model ADDIE. Al-Fathin, Vol. 1, No. 2.

Yuli Anggraeni, M. N. (2016). Pengembangan Media Pembelajaran Pocket Book untuk Meningkatkan Motivasi Belajar Siswa pada Pelajaran PAM. Jurnal Kajian Pendidikan Akuntansi Indonesia, Vol. 5, No. 2.

Zaenuddin, R. (2009). Metodologi dan Strategi Alternatif Pembelajaran Bahasa Arab. Yogyakarta: Pustaka Rihlah Pustaka. 